Transactions of the American Fisheries Society, 1996, vol.125, no.5, p.753-759.

DOI: $10.1577 / 1548-8659(1996) 125<0753$ :FPOOGS $>2.3 . C O ; 2$

ISSN: (print 0002-8487); (online 1548-8659)

http://www.fisheries.org

http://afsjournals.org/loi/fitr

http://afsjournals.org/doi/pdf/10.1577/1548-8659\%281996\%29125\%3C0753\%3AFPOOGS\%3E2.3.CO\%3B2

(C) 1996 American Fisheries Society 


\title{
Feeding Preferences of Omnivorous Gizzard Shad as Influenced by Fish Size and Zooplankton Density
}

\author{
Lisa A. Yako,' John M. DetTmers, ${ }^{2.3}$ AND Roy A. STein \\ Aquatic Ecology Laboratory, Department of Zoology \\ The Ohio State University. Columbus, Ohio 43212-1194. USA
}

\begin{abstract}
In Ohio reservoirs, larval gizzard shad Dorosoma cepedianum less than $30 \mathrm{~mm}$ total length consume only zooplankton but frequently switch to detritus as they grow longer than 30 $\mathrm{mm}$. However. in laboratory studies without detritus, gizzard shad longer than $30 \mathrm{~mm}$ consume crustacean zooplankton. To explore the composition of diets of omnivorous $30-100-\mathrm{mm}$ gizzard shad, we completed I-h laboratory feeding trials with different amounts of zooplankton and detritus and quantified the diets of gizzard shad in reservoirs. In both laboratory and field, gizzard shad ate primarily detritus but also ate zooplankton, consuming more as more became available. which demonstrates that this species is a facultative detritivore. In the field, zooplankton consumption declined as gizzard shad body size increased. We believe gizzard shad maximize growth by supplementing their low-protein detritus diet with more zooplankton as more becomes available. With this strategy, omnivorous gizzard shad may compromise the potential for food web manipulations based on the trophic cascade hypothesis in Ohio reservoirs.
\end{abstract}

Gizzard shad Dorosoma cepedianum often dominate fish communities in reservoirs (Jenkins 1967; Cramer and Marzolf 1970; Noble 1981; Johnson et al. 1988) and regulate summer zooplankton (Dettmers and Stein 1992; DeVries and Stein 1992; Dettmers and Stein 1996; Dettmers et al. 1996). As larvae less than $30 \mathrm{~mm}$ total length (TL), gizzard shad consume zooplankton almost exclusively (Bodola 1966; Cramer and Marzolf 1970; Dettmers and Stein 1992), reducing crustacean zooplankton to less than 20 individuals $/ L$ (Bremigan et al. 1991; DeVries and Stein 1992). By reducing crustacean zooplankton, gizzard shad exacerbate exploitative competition among reservoir fishes dependent on limited zooplankton (e.g.. bluegill Lepomis macrochirus), perhaps compromising recruitment of these fishes (Guest et al. 1990; DeVries et al. 1991; Dettmers and Stein 1992; Stein et al. 1995).

Beyond $30 \mathrm{~mm}$ TL, gizzard shad become omnivorous pump-filter feeders consuming not only zooplankton, but also detritus (Bodola 1966; Cramer and Marzolf 1970; Drenner et al. 1982). Historically, this dietary shift has been attributed to low crustacean zooplankton availability because field evidence revealed that gizzard shad greater than $38 \mathrm{~mm}$ TL consumed primarily detritus (Mun-

\footnotetext{
I Present address: Massachusetts Cooperative Fish and Wildlife Research Unit, University of Massachusetts, Amherst, Massachusetts 01003-4220, USA.

2 To whom correspondence should be addressed.

${ }^{3}$ Present address: Illinois Natural History Survey, 4134 Alby Street, Alton, Illinois 62002, USA.
}

dahl and Wissing 1987, 1988; Mundahl 1988, 1991), whereas gizzard shad 57-189 mm TL consumed crustacean zooplankton in laboratory pools without detritus (Drenner et al. 1982).

Composition of gizzard shad's diet probably influences the fishes' growth potential. Although gizzard shad can feed selectively on energy-rich detritus (Mundahl and Wissing 1988), detritus is low in protein and frequently compromises growth (Bowen et al. 1995). Hence, gizzard shad that consume more crustacean zooplankton may experience a growth advantage.

The potentially broad range of foods consumed by omnivorous gizzard shad greater than $30 \mathrm{~mm}$ may influence their impact on crustacean zooplankton resources, depending on whether gizzard shad alter their feeding preference when exposed to different crustacean zooplankton densities. Specifically, if gizzard shad greater than $30 \mathrm{~mm}$ are obligate detritivores, they will have little impact on crustacean zooplankton abundance. Conversely, as facultative detritivores, gizzard shad may continue to strongly influence crustacean zooplankton resources even beyond $30 \mathrm{~mm}$. To determine whether omnivorous gizzard shad behave as obligate or facultative detritivores, we completed feeding trials with different densities of crustacean zooplankton and detritus, and then compared these results to age-0 gizzard shad diets in reservoirs.

\section{Methods}

Laboratory experiments.-Gizzard shad were collected by electrofishing from Kokosing Lake 
(Knox County, Ohio; detailed description given later) during March and April 1992 and maintained in the laboratory with nauplii of Artemia spp. for at least 2 weeks before experiments began. Detritus was collected from the littoral zone of Kokosing Lake in March 1992, whereas crustacean zooplankton (hereafter zooplankton) was obtained from ponds at the Hebron State Fish Hatchery (Licking County, Ohio) during March and April 1992.

We established four treatments: (1) high zooplankton (100 zooplankters/L; biomass about 100 $\mu \mathrm{g} / \mathrm{L}$ ) only (HZPO; $N=5$ replicates), (2) high zooplankton and detritus (HZPD; $N=5$ ), (3) low zooplankton ( 20 zooplankters/L; biomass about 20 $\mu \mathrm{g} / \mathrm{L}$ ) and detritus (LZPD; $N=5$ ), and (4) detritus only (DO: $N=3$ ). Both HZPO and HZPD reflect zooplankton densities in Clark Lake (see below). We chose LZPD because gizzard shad frequently drive zooplankton below $20 / \mathrm{L}$ in reservoirs (DeVries et al. 1991; Dettmers and Stein 1992; DeVries and Stein 1992) and matched densities in Kokosing Lake.

Mean total lengths of gizzard shad in experiments were HZPO $(N=10), 101.60 \pm 5.36 \mathrm{~mm}$ (mean \pm 1 SE); HZPD $(N=10), 105.00 \pm 5.18$ $\mathrm{mm}$; LZPD $(N=10), 103.30 \pm 2.40 \mathrm{~mm}$; and DO $(N=6), 74.17 \pm 1.99 \mathrm{~mm}$. Gizzard shad in the DO treatment were smaller than fish in other treatments (analysis of variance [ANOVA]: $F=5.31$, df $=3,14, P=0.01$; Tukey's multiple comparisons, $P<0.05$ ); hence, all comparisons among treatments were evaluated as micrograms of zooplankton or detritus (dry weight) consumed per gram of wet body weight of gizzard shad to correct for absolute differences in amount of food in guts.

Detritus $(3-5 \mathrm{~cm})$ and zooplankton were added to 114-L aquaria $4 \mathrm{~d}$ and $24 \mathrm{~h}$, respectively, before experiments began. Zooplankton were dominated by Bosmina spp. but also contained nauplii and copepods. Organic plus inorganic material comprised detritus; the organic fraction included both fine and coarse particulates, whereas the inorganic fraction consisted of silt, clay, and sand. We maintained zooplankton in experimental aquaria with algae and did not remove shed zooplankton carapaces from the tanks between trials; hence, carapaces and algae occurred in all treatments and were considered part of the detritus.

During experiments, two gizzard shad, starved for $24 \mathrm{~h}$ to permit complete gut evacuation, were added to an aquarium, allowed to feed for $1 \mathrm{~h}$, and then removed, measured (nearest millimeter total length), and frozen for later analysis. During each replicate, we recorded feeding behavior of one randomly chosen gizzard shad. Position in the water column (upper, midlevel, bottom) was recorded every $30 \mathrm{~s}$; feeding activity was recorded every 3 min as the number of feeding gulps during $1 \mathrm{~min}$. After each replicate, zooplankton remaining were estimated with a tube sampler $(30-\mathrm{mm}$ inside diameter; $N=3$ hauls/aquarium; total volume sampled, $\sim 600 \mathrm{~mL}$ ); zooplankton densities were then increased to original treatment levels in preparation for the next replicate. Replicates of each treatment were run at intervals of at least $24 \mathrm{~h}$ to permit settling of detritus.

To quantify gizzard shad diets, we removed both pharyngeal pockets, the foregut, and the gizzard (hereafter, collectively called the gut). We examined gut contents with a dissecting microscope, measured all intact zooplankters (nearest $0.01 \mathrm{~mm}$ ) when possible, and converted length to dry biomass (Dumont et al. 1975; Bottrell et al. 1976; Culver et al. 1985). When possible, damaged zooplankters within each gut were identified and assigned a total length equal to the mean length of their taxon. Zooplankton carapaces found in guts were considered part of the detritus because they had been shed from zooplankters before ingestion. Gut contents were dried for $24 \mathrm{~h}$ at $60^{\circ} \mathrm{C}$. We calculated total zooplankton dry weight in each gut by summing individual zooplankton weights. Detritus dry weight was the difference between calculated zooplankton weight and weight of the gut contents.

Gizzard shad wet weights were calculated as per Johnson et al. (1988):

$$
\log _{e}(W)=3.357 \log _{e}(L)-12.97 ;
$$

$W=$ wet body weight $(\mathrm{g})$, and $L=$ total length (mm).

We analyzed overall treatment effects using oneway ANOVA and used Tukey's multiple comparisons to examine treatment differences.

Field pattern.-Kokosing Lake was a 65 -ha reservoir with $7.5 \mathrm{~km}$ of shoreline, a mean depth of $2.0 \mathrm{~m}$ (maximum depth $=4.9 \mathrm{~m}$ ), and Secchi depths typically less than $1 \mathrm{~m}$. Neither submersed nor emergent vegetation was abundant. Clark Lake (Clark County, Ohio) was a 40-ha reservoir with $4.5 \mathrm{~km}$ of shoreline, a mean depth less than $1.0 \mathrm{~m}$ (maximum depth $=2.0 \mathrm{~m}$ ), and typical Secchi depths from 25 to $75 \mathrm{~cm}$. Emergent vegetation (Typha spp.) occupied about $25 \%$ of the shoreline. Fish communities in both lakes included gizzard shad, largemouth bass Micropterus salmoides, 


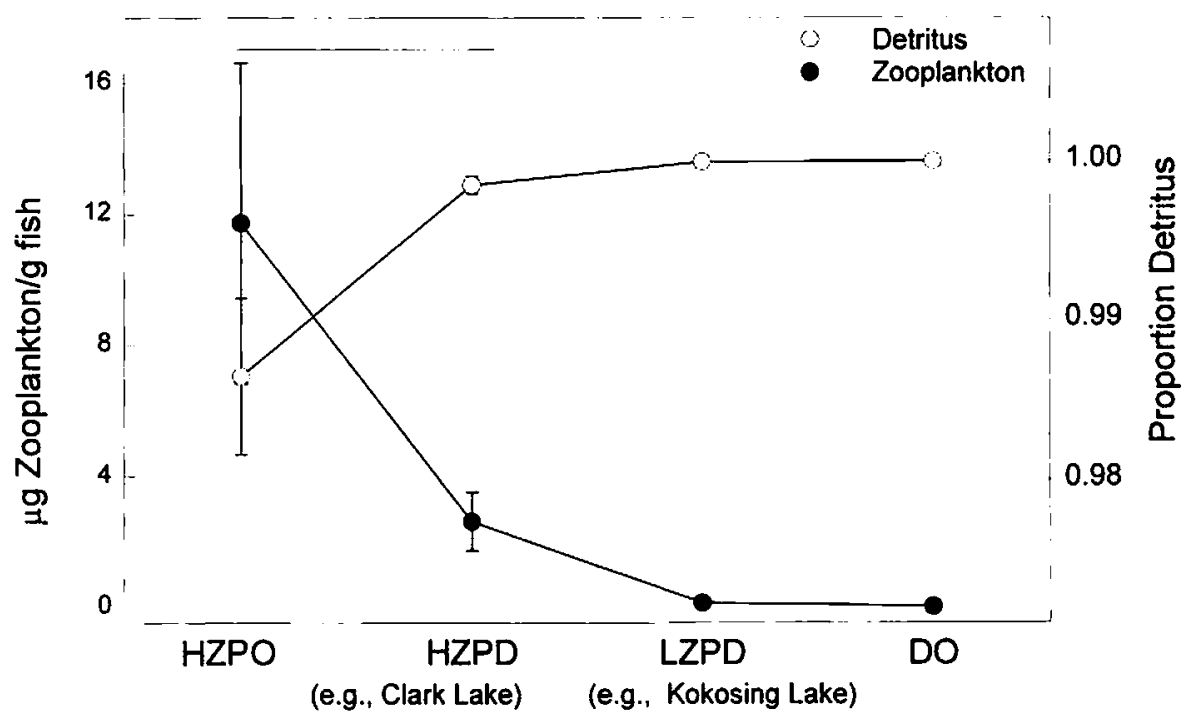

Figure 1.-Mean crustacean zooplankton dry biomass ( \pm I SE) consumed per gram wet body weight of gizzard shad (left y-axis; solid circles) and mean percent detritus in gizzard shad guts (right y-axis; open circles) during experiments in 114-L aquaria. We used 10 replicate fish in each aquarium treatment, except for DO, in which only 6 tish were used; HZPO, zooplankton only; HZPD. high zooplankton plus detritus: LZPD. low zooplankton plus detritus; DO, detritus only. The horizontal line in the upper left signifies similar zooplankton consumption, as determined by Tukey's multiple comparisons $(P>0.05)$.

white crappie Pomoxis annularis, bluegill Lepomis macrochirus, and common carp Cyprinus carpio.

We collected age- 0 gizzard shad by electrofishing or seining from Kokosing Lake on six dates during June through November and from Clark Lake on seven dates during July through August 1992. Fish were immediately placed on ice. Gut contents of 7-15 fish collected from each date and lake were quantified as described earlier.

While seine samples were being taken, zooplankton samples ( $16-33 \mathrm{~L}$ per sample, $N=3$ sites per date) were collected with a tube sampler $(2 \mathrm{~m}$ long, $72 \mathrm{~mm}$ inside diameter). Each sample was then filtered through a 54- $\mu \mathrm{m}$ mesh net, preserved in $70 \%$ ethyl alcohol, and counted as per Stahl and Stein (1994). Up to 20 individuals of each taxon in a sample were measured (nearest $0.01 \mathrm{~mm}$ ), allowing us to calculate biomass using taxon-specific, length-dry weight regressions (Dumont et al. 1975; Bottrell et al. 1976; Culver et al. 1985).

We evaluated weight-specific zooplankton consumption $(\mu \mathrm{g}$ zooplankton dry weight/g fish wet weight) by age-0 gizzard shad using regression analysis. Data were log-transformed to satisfy normality assumptions.

\section{Results}

\section{Laboratory Experiments}

Gizzard shad consumed zooplankton in all treatments with zooplankton. Zooplankton biomass consumed differed significantly among treatments (ANOVA: $F=3.52$, df $=3,14, P=0.04$; Figure 1). Gizzard shad in the HZPO and HZPD treatments consumed similar amounts of zooplankton but more zooplankton than gizzard shad in the LZPD treatment (Tukey's multiple comparisons, $P$ $=0.05$ : Figure 1).

Gizzard shad in all treatments consumed primarily detritus. Detritus consumed did not significantly differ among treatments (ANOVA: $F=$ 0.59 . $\mathrm{df}=3,14, P=0.63$ ). Percent detritus in gizzard shad guts varied from $98.6 \%$ in the HZPO treatment to $100 \%$ in the DO treatment (Figure 1).

Gizzard shad in all treatments spent $86 \%$ of their time swimming in the water column. Most feeding activity $(>85 \%)$ occurred in midwater rather than near the bottom because gizzard shad frequently approached very close to the bottom, sending clouds of detritus into the water where they could filter it from the water column. Number of feeding gulps per minute did not significantly differ among treatments (ANOVA: $F=0.09$, df $=3,14, P=$ 0.97).

\section{Field Pattern}

Zooplankton in Clark Lake were dominated by nauplii, with Diaphanosoma spp. secondarily important. In Kokosing Lake, zooplankton were 




FIGURE 2.-Mean crustacean zooplankton dry biomass ( \pm 1 SE) consumed per gram wet body weight of gizzard shad (left $y$-axis) and mean percent detritus in gizzard shad guts (right $y$-axis), as for 10-mm size-classes in (A) Clark Lake and (B) Kokosing Lake, Ohio, during June-November 1992. Numbers in parentheses reflect sample sizes for each size-class.

dominated by nauplii, Diaphanosoma spp., and calanoid copepods. Mean crustacean zooplankton density and biomass differed significantly between lakes ( $t$-tests, $P=0.0001$ ). Clark Lake zooplankIon density and biomass persisted at high levels during 2 July-9 September, maintaining density at $64-158 / \mathrm{L}$ and biomass at $90-196 \mu \mathrm{g} / \mathrm{L}$. Kokosing Lake zooplankton density and biomass remained low during 25 June-9 September, declining to zero on 15 July and never increasing above $25 / \mathrm{L}$ and $27 \mu \mathrm{g} / \mathrm{L}$, respectively.

Total lengths of gizzard shad from Clark $(N=$ $87)$ and Kokosing $(N=62)$ lakes were $52.6 \pm 1.9$ $\mathrm{mm}$ (mean $\pm \mathrm{SE}$ ) and $51.8 \pm 11.7 \mathrm{~mm}$, respectively. Gizzard shad from Kokosing and Clark lakes consumed primarily detritus (Figure 2). Weight-specific detritus consumption did not significantly differ between lakes (paired $t$-test, $P=$ 0.88 ). No other trends in detritus consumption were evident, either between lakes or across fish size. Gizzard shad always consumed more than 97\% detritus (Figure 2).

Weight-specific zooplankton consumption declined as gizzard shad grew from 30 to $60 \mathrm{~mm}$ in both reservoirs (Figure 2). Gizzard shad from 60 to $100 \mathrm{~mm}$ maintained constant, low zooplankton 
TABLE 1.-Regressions predicting the weight-specitic amount of zooplankton in age- 0 gizzard shad guts ( $\mu g / g)$ during June-November 1992 in Clark and Kokosing lakes combined. The regression model for both reservoirs was loge (zooplankton biomass in gut) $=a+b\left(\log _{e}\right.$ gizzard shad size $)+c\left(\log _{e}\right.$ zooplankton biomass in reservoir). Partial $r^{2}$ refers to the partial coeflicient of determination; one interprets it as the reduction in error by adding the given variable. assuming the other is already in the model. Zooplankton biomass available in each lake is denoted by $Z$ P.

\begin{tabular}{|c|c|c|c|c|c|c|c|}
\hline \multirow{2}{*}{$\begin{array}{l}\text { Dependent } \\
\text { variable }\end{array}$} & \multicolumn{3}{|c|}{ Regression coefficients } & \multirow{2}{*}{$\begin{array}{c}\text { Sum of squares } \\
\text { (regression) }\end{array}$} & \multirow{2}{*}{$\begin{array}{l}\text { Sum of squares } \\
\text { (error) }\end{array}$} & \multirow[b]{2}{*}{ Adjusted $R^{2}$} & \multirow[b]{2}{*}{ Partial $r^{2}$} \\
\hline & $a$ & $b$ & $c$ & & & & \\
\hline Size and $Z P$ & 9.34 & -2.77 & 0.68 & 41.04 & 22.98 & 0.62 & \\
\hline Size & 11.36 & -2.60 & & 23.28 & 40.73 & & 0.53 \\
\hline ZP & -1.00 & & 0.62 & 14.80 & 49.22 & & 0.44 \\
\hline
\end{tabular}

consumption. Regression analysis with data from both reservoirs revealed that zooplankton consumption declined with increasing gizzard shad size, but increased as zooplankton biomass increased (Table 1; Figure 3). In fact, zooplankton consumption by gizzard shad declined as a function of body size at similar rates in both lakes (test for homogeneity of slopes, $F<0.01$; $\mathrm{df}=1.26$; $P=0.99$ ), but was always greater in Clark Lake (test for equal intercepts, $F=16.98$, $\mathrm{df}=1,26$, $P=0.0003$ ). Despite the decline of zooplankton consumption with size, this decline did not affect the capacity of gizzard shad to consume more zooplankton if more was available. However, the stronger determinant of overall gizzard shad consumption was gizzard shad size (Table 1).

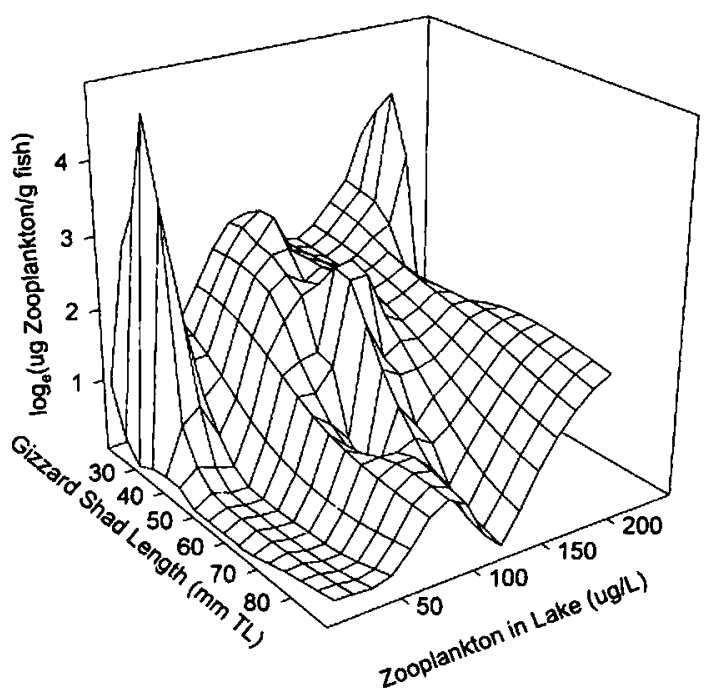

Figure 3.-Response curve of dry biomass of mean crustacean zooplankton consumed per gram wet body weight of gizzard shad versus lakewide zooplankton biomass available and gizzard shad size-class in Clark and Kokosing lakes, Ohio, during June-November 1992.

\section{Discussion}

With laboratory and field data, we have described the response of $30-100-\mathrm{mm}$ gizzard shad to variable amounts of zooplankton. In both shortterm laboratory experiments and in reservoirs, gizzard shad consumed more zooplankton if more became available. Regardless of zooplankton density in the field, weight-specific zooplankton consumption by gizzard shad declined 1-3 orders of magnitude as gizzard shad grew from 30 to $90 \mathrm{~mm}$.

When zooplankton biomass exceeded $90 \mu \mathrm{g} / \mathrm{L}$ (HZPD treatment and Clark Lake), 60-100-mm gizzard shad consumed 1-3 $\mu \mathrm{g}$ zooplankton/g fish, whereas when zooplankton biomass fell below 27 $\mu \mathrm{g} / \mathrm{L}$ (LZPD treatment and Kokosing Lake), 60100-mm gizzard shad ate $0.1-0.3 \mu \mathrm{g}$ zooplankton/g fish. Interestingly, zooplankton consumption declined by an order of magnitude as zooplankton biomass declined by $70 \%$ from Clark to Kokosing Lake.

This dietary pattern of gizzard shad is consistent with that reported in the literature. Although zooplanktivorous as larvae, larger gizzard shad consume zooplankton, phytoplankton, and detritus (Miller 1960; Bodola 1966), frequently feeding primarily on detritus (Mundahl 1988). This decline in zooplankton in diets of gizzard shad greater than $30 \mathrm{~mm}$ likely reflects reduced requirements for protein as growth slows because protein frequently limits growth in detritivores (Bowen et al. 1995). To maintain high growth as larvae, when essential amino acids are required for tissue development, gizzard shad consume only zooplankton (Dettmers and Stein 1992; DeVries and Stein 1992). Because protein becomes less limiting as growth slows, omnivorous gizzard shad greater than $30 \mathrm{~mm}$ can still generate sufficient caloric intake by increasing detritus consumption, thus compensating for reduced food quality (Bowen et al. 1995).

We conclude that gizzard shad are facultative, rather than obligate, detritivores. Although gizzard 
shad do consume less zooplankton as they grow, they also eat more zooplankton if more becomes available. To ensure high growth rates, thus reducing their vulnerability to piscivores (Johnson et al. 1988), gizzard shad should seek to consume as much protein-rich invertebrate prey as possible.

This pattern of zooplankton consumption by omnivorous gizzard shad may have important implications for reservoir food webs. For instance, omnivorous gizzard shad can persist at very low zooplankton abundance (Mundahl 1991), whereas recruitment success of sport fishes with zooplanktivorous larvae requires zooplankton densities exceeding 100/L (Werner and Blaxter 1980; Eldridge et al. 1981; Li and Mathias 1982). Conceivably, when gizzard shad feed primarily on detritus, zooplankton abundance will increase if conditions are favorable for growth and reproduction of zooplankton, again permitting recruitment by zooplanktivores. However, our results suggest that any tendency for increased zooplankton abundance may be offset by increased zooplankton consumption by omnivorous gizzard shad, depending on their size, their population density, and zooplankton productivity (Dettmers and Stein 1996; Dettmers et al. 1996). In our view, successfully manipulating reservoir food webs by the trophic cascade specifically to increase zooplankton is unlikely in the presence of omnivorous gizzard shad.

\section{Acknowledgments}

We thank J. E. Garvey and H. M. Thomas for help collecting fish. We appreciate the statistical advice of E. A. Marschall. M. W. Kershner, and J. R. Robb. Constructive comments on an earlier draft by T. A. Crowl, D. R. DeVries, and N. D. Mundahl substantially improved the manuscript. This work was supported by Federal Aid in Sport Fish Restoration project F-57-R, administered jointly by the U.S. Fish and Wildlife Service and the Ohio Division of Wildlife, to R.A.S.

\section{References}

Bodola, A. 1966. Life history of the gizzard shad, Dorosoma cepedianum (LeSueur), in western Lake Erie. U.S. National Marine Fisheries Service Fishery Bulletin 65:391-425.

Bottrell, H. H., and eight coauthors. 1976. A review of some problems in zooplankton production studies. Norwegian Journal of Zoology 24:419-456.

Bowen. S. H., E. V. Lutz, and M. O. Ahlgren. 1995. Dietary protein and energy as determinants of food quality: trophic strategies compared. Ecology 76: 899-907.

Bremigan, M. T., E. M. Lewis, M. B. Jones, and R. A.
Stein. 1991. Evaluating effects of stocking threadtin shad on young-of-year crappie, bluegill, and largemouth bass in Ohio lakes. Ohio Department of Natural Resources, Federal Aid in Sport Fish Restoration Project F-57-R-11, Annual Report, Columbus.

Cramer. J. D., and G. R. Marzolf. 1970. Selective predation on zooplankton by gizzard shad. Transactions of the American Fisheries Society 99:320332.

Culver, D. A.. M. M. Boucherle, D. J. Bean, and J. W. Fletcher. 1985. Biomass of freshwater crustacean zooplankton from length-weight regressions. Canadian Journal of Fisheries and Aquatic Sciences 42:1380-1390.

Dettmers, J. M., D. R. DeVries, and R. A. Stein. 1996. Quantifying responses to hybrid striped bass predation across multiple trophic levels: implications for reservoir biomanipulation. Transactions of the American Fisheries Society 125:49 I-504.

Dettmers, J. M., and R. A. Stein. 1992. Food consumption by larval gizzard shad: zooplankton effects and its implications for reservoir communities. Transactions of the American Fisheries Socicty 121: 494-507.

Dettmers, J. M., and R. A. Stein. 1996. Quantifying linkages among gizzard shad, zooplankton, and phytoplankton in reservoirs. Transactions of the American Fisheries Society 125:27-41.

DeVries, D. R., and R. A. Stein. 1992. Complex interactions between fish and zooplankton: quantifying the role of an open-water planktivore. Canadian Journal of Fisheries and Aquatic Sciences 49:12161227.

DeVries, D. R., R. A. Stein, J. G. Miner, and G. G. Mittelbach. 1991. Stocking threadfin shad: consequences for young-of-year fishes. Transactions of the American Fisheries Society 120:368-381.

Drenner. R. W. W. J. O'Brien, and J. R. Mummert. 1982. Filter-feeding rates of gizzard shad. Transactions of the American Fisheries Society 111:210-215.

Dumont. H. J., I. Van de Velde, and S. Dumont. 1975. The dry weight estimate of biomass in a selection of Cladocera. Copepoda and Rotifera from the plankton, periphyton and benthos of continental waters. Oecologia 19:75-97.

Eldridge, M. B., J. A. Whipple, D. Eng, M. J. Bowers, and B. M. Jarvis. 1981. Effects of food and feeding factors on laboratory reared striped bass larvae. Transactions of the American Fisheries Society 110 : 111-120.

Guest, W. C.. R. W. Drenner, S. T. Threlkeld, F. D. Martin, and J. D. Smith. 1990. Effects of gizzard shad and threadfin shad on zooplankton and young-ofyear white crappie production. Transactions of the American Fisheries Society 119:529-536.

Jenkins, R. M. 1967. The influence of some environmental factors on standing crop and harvest of fishes in U.S. reservoirs. Pages 298-321 in Reservoir Fishery Resources Symposium. American Fisheries Society, Southern Division, Reservoir Committee, Bethesda, Maryland. 
Johnson, B. M., R. A. Stein, and R. F. Carline. 1988. Use of a quadrat rotenone technique and bioenergetics modeling to evaluate prey availability to stocked piscivores. Transactions of the American Fisheries Society 117:127-141.

Li. S., and J. A. Mathias. 1982. Causes of high mortality among cultured larval walleyes. Transactions of the American Fisheries Society 111:710-721.

Miller, R. R. 1960. Systematics and biology of the gizzard shad (Dorosoma cepedianum) and related fishes. U.S. National Marine Fisheries Service Fishery Bulletin 60(173):371-392.

Mundahl, N. D. 1988. Nutritional quality of foods consumed by gizzard shad in western Lake Erie. Ohio Journal of Science 88:110-113.

Mundahl, N. D. 1991. Sediment processing by gizzard shad, Dorosoma cepedianum (LeSueur), in Acton Lake, Ohio, U.S.A. Journal of Fish Biology 38:565572.

Mundahl, N. D., and T. E. Wissing. 1987. Nutritional importance of detritivory in the growth and condition of gizzard shad in an Ohio reservoir. Environmental Biology of Fishes 20:129-142.

Mundahl, N. D., and T. E. Wissing. 1988. Selection and digestive efficiencies of gizzard shad feeding on natural detritus and two laboratory diets. Transactions of the American Fisheries Society 117:480487.

Noble, R. L. 1981. Management of forage tishes in impoundments of the southern United States. Transactions of the American Fisheries Society 1 10:725728.

Stahl, T. P., and R. A. Stein. 1994. The influence of larval gizzard shad density on piscivory and growth of young-of-year saugeye (Stizostedion vitreum vitreum $\times S$. canadense). Canadian Journal of Fisheries and Aquatic Sciences 51:1993-2002.

Stein, R. A.. D. R. DeVries. and J. M. Dettmers. 1995. Food-web regulation by a planktivore: exploring the generality of the trophic cascade hypothesis. Canadian Journal of Fisheries and Aquatic Sciences 52:2518-2526.

Werner, R. G., and J. H. S. Blaxter. 1980. Growth and survival of larval herring, Clupea harengus, in relation to fry density. Canadian Journal of Fisheries and Aquatic Sciences 37:1063-1069.

Received May 23, 1995 Accepted May 4. 1996 